\title{
Pozdní protézová endokarditida
}

\author{
Jiří Král, Vilém Rohn* \\ 3. interní klinika, *2. chirurgická klinika kardiovaskulární chirurgie, Všeobecná fakultní nemocnice a 1. lékařská fakulta Univerzity \\ Karlovy, Praha, Česká republika
}

Úvod: Infekční endokarditida na chlopenních náhradách - prostetická endokarditida (PVE, z anglického názvu prosthetic valve endocarditis) představuje vždy závažnou komplikaci. Incidence PVE během prvního roku po implantaci kolísá mezi 1-3\%. Infekce postihuje se stejnou frekvencí aortální i mitrální lokalizaci, mechanické náhrady i bioprotézy. Po dvanácti měsících od implantace chlopenní náhrady incidence PVE významně klesá, činí přibližně $0,4 \%$ ročně.

U časné PVE se mikroorganismy dostávají na chlopenní náhradu bud' přímou kontaminací intraoperativně, nebo při bakteriemii $\mathrm{v}$ prvních dnech a týdnech po operaci. Infekce se zachycuje na chlopni a snadno proniká do perivalvulární tkáně podél operačních stehů, protože tyto struktury nejsou po operaci ještě endotelizovány. Chlopeň je v tu dobu kryta pouze proteiny, jako je fibronektin a fibrinogen, na které mohou adherovat některé mikroorganismy a iniciovat infekci. U pozdní PVE je, vzhledem k pokrytí prstence chlopně i stehů endotelem, patogeneze vzniku infekční endokarditidy již odlišná a blíží se svou epidemiologií, mikrobiologií a klinickým obrazem infekční endokarditidě na nativních chlopních.

Na rozdíl od časné PVE, u které je výrazná tendence k šírení infekce perivalvulárně, s častým vznikem dehiscence chlopenní náhrady, paravalvulární regurgitace a paravalvulárních abscesů, zůstávají u pozdní PVE vegetace obvykle přichyceny na prstencích nebo cípech chlopně (u bioprotéz). Infekce je méně invazivní,

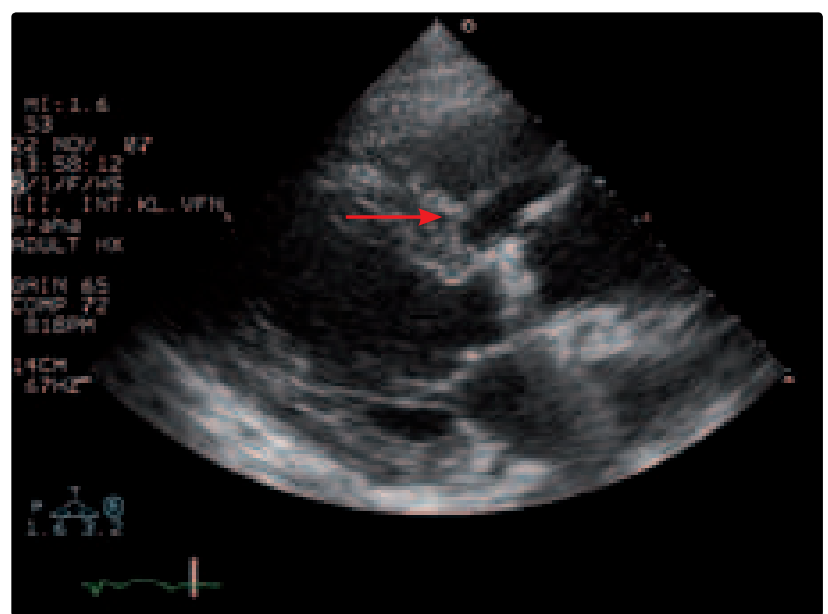

Obrázek 2 Transthorakální echokardiografie (TTE). Parasternální dlouhá osa.

Šipkou je označena dutina v přední stěně aorty po vyprázdněném abcesu.

tendence $k$ šíření do okolí náhrady je podstatně nižší. Riziko invazivního perivalvulárního šíření infekce je však i u pozdní PVE zvýšeno, pokud se jedná o recidivující PVE nebo je vyvolávajícím infekčním agens zlatý stafylokok.

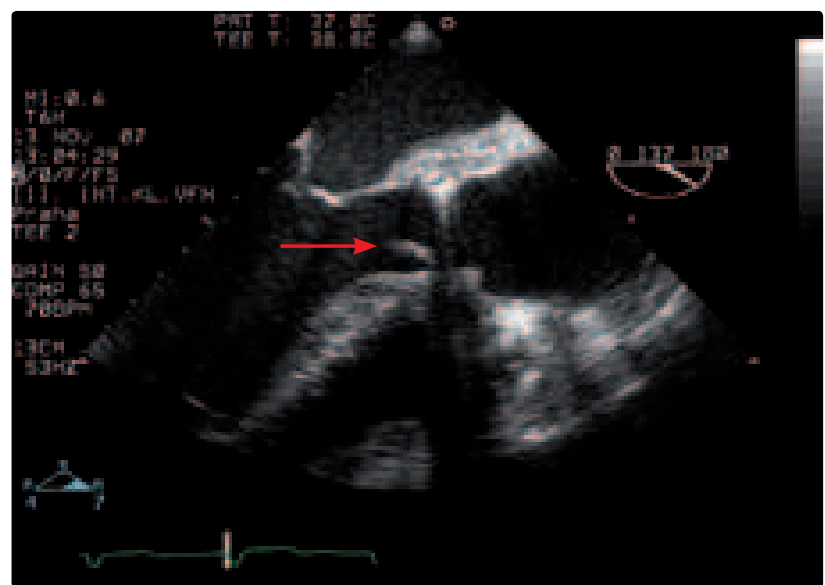

Obrázek 1 Jícnová echokardiografie (TEE). Projekce na dlouhou osu levé komory.

Šipkou je označena vegetace na diskové chlopenní náhradě vlající v diastole do výtokového traktu levé komory.

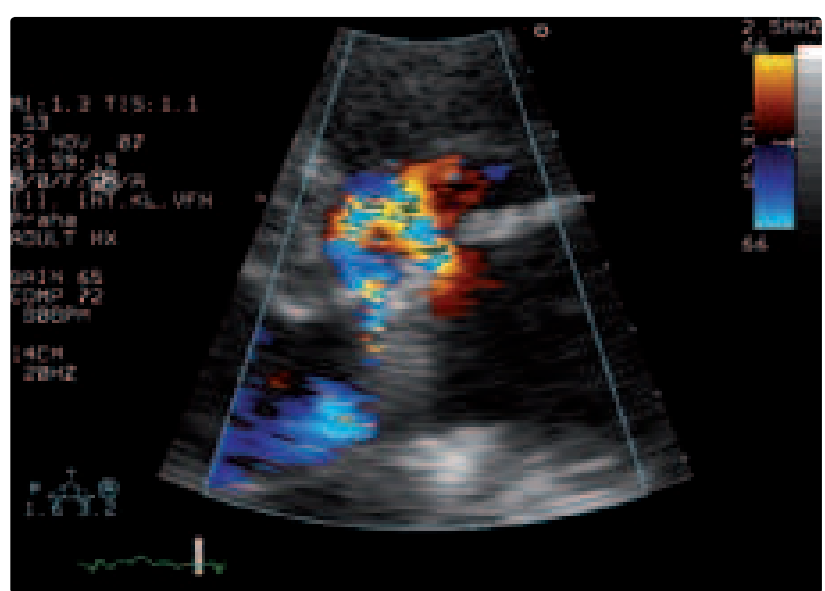

Obrázek 3 Transthorakální echokardiografické vyšetření. Parasternální dlouhá osa. Zvětšené zobrazení chlopenní náhrady.

Barevné dopplerovské mapování ukazuje patologickou komunikaci mezi abscesem, aortou a výtokovým traktem levé komory. 


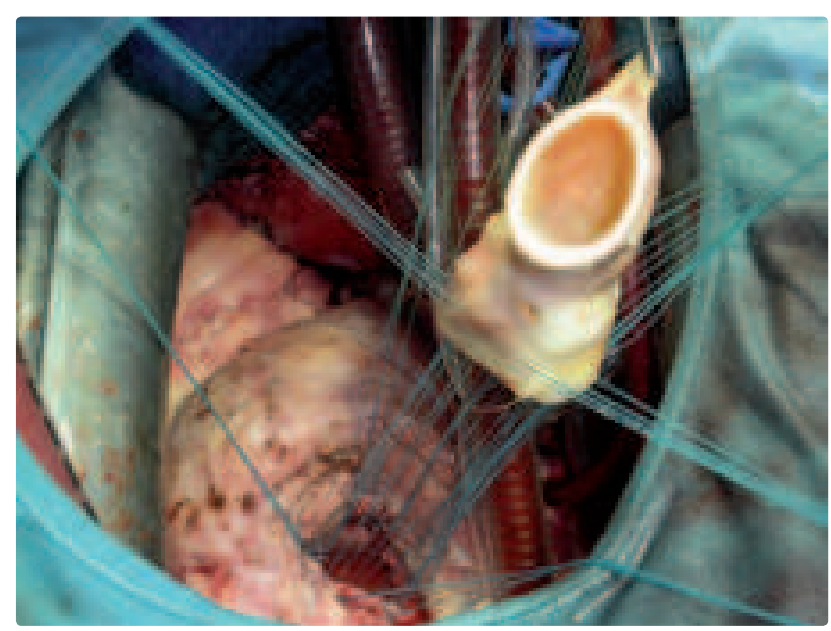

Obrázek 4 Peroperační nález. Stav po odstranění diskové chlopenní náhrady v aortální pozici. Na místo patologicky změněné náhrady a aorty je implantován homograft.

Kasuistika: 56letý nemocný po náhradě stenotické bikuspidální aortální chlopně, po reoperaci pro náhodně diagnostikovanou komunikující dutinu v zadní stěně aorty, která vznikla nejspíše po vyprázdněném paravalvulárním abscesu, byl přijat pro klinický obraz pozdní PVE s teplotami a mnohočetnými septickými embolizacemi (centrální nervová soustava, játra, slezina, ledviny). Diagnóza byla potvrzena jícnovou echokardiografií s nálezem vlající vegetace, přisedlé na přední části prstence mechanické náhrady (obrázek 1). Byla zachycena i pozitivní hemokultura (Staphylococcus aureus). Vzhledem k recidivující PVE a opakovaným mnohočetným septickým embolizacím byl nemocný indikován $\mathrm{k}$ elektivní operaci - náhradě aortální chlopně a části ascendentní aorty homograftem. Den před plánovaným kardiochirurgickým výkonem došlo ke změně poslechového nálezu na srdci s nově vzniklým systolickým šelestem nad srdeční bází. Provedené kontrolní echokardiografické vyšetření (obrázek 2) odhalilo vývoj paravalvulárního abscesu $\mathrm{v}$ přední stěně aorty, s dehiscencí náhrady, s patologickou komunikací podél chlopně do oblasti kořene aorty a výtokového traktu levé komory (obrázek 3). Pacient byl akutně přeložen na kardiochirurgické oddělení pro př́pad nutného urgentního výkonu. Vzhledem ke stabilizovanému stavu, bez progrese aortální insuficience, bylo možno situaci řešit podle původního plánu následující den implantací homograftu do aortální pozice (obrázek 4).

\section{Literatura}

1. Wang $A$, Athan $E$, Pappas $P A$, et al. Contemporary clinical profile and outcome of prosthetic valve endokarditis. JAMA 2007;297:1354-61.

2. Foghsgaard S, Bruun N, Kjaergard H. Outcome of aortic homograft implantation in 24 cases of severe infective endocarditis. Scand J Infect Dis 2008; 40:216-20. 